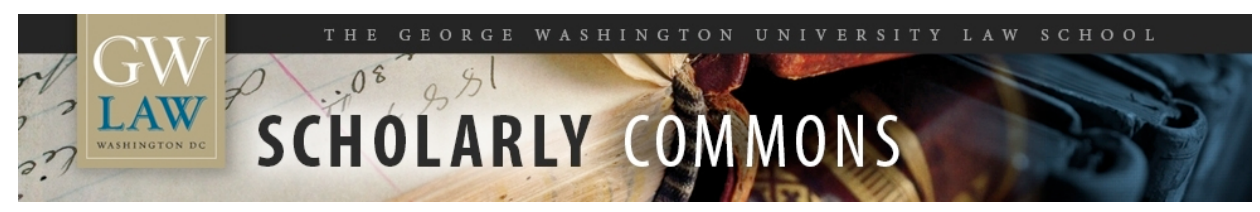

\title{
The Limitation on Exclusion of Extrinsic Evidence
}

Stephen A. Saltzburg

George Washington University Law School, ssaltz@law.gwu.edu

Follow this and additional works at: https://scholarship.law.gwu.edu/faculty_publications

Part of the Law Commons

\section{Recommended Citation}

Saltzburg, Stephen A., The Limitation on Exclusion of Extrinsic Evidence (2014). 29 Crim. Just. (2014) ; GWU Law School Public Law Research Paper No. 2014-61; GWU Legal Studies Research Paper No. 2014-61. Available at SSRN: http://ssrn.com/abstract=2663617

This Article is brought to you for free and open access by the Faculty Scholarship at Scholarly Commons. It has been accepted for inclusion in GW Law Faculty Publications \& Other Works by an authorized administrator of Scholarly Commons. For more information, please contact spagel@law.gwu.edu. 


\section{The Limitation on Exclusion of Extrinsic Evidence}

\section{BY STEPHEN A. SALTZBURG}

$\mathrm{F}$ ederal Rule of Evidence 608(b) prohibits the admission of extrinsic evidence "to prove specific instances of a witness's conduct in order to attack or support the witness's character for truthfulness." The rule was amended in 2003 to substitute the words "character for truthfulness" for the word "credibility" in an effort to make clear that the intent of the prohibition on extrinsic evidence was and is to exclude extrinsic evidence offered to prove a witness's general propensity for truthfulness or untruthfulness. Despite the Advisory Committee's effort to clarify the limits on the ban on extrinsic evidence, courts frequently find the rule confusing. Most states have similar rules that are equally confusing.

\section{United States v. Delgado-Marrero}

An illustrative case is United States v. Delgado-Marrero, 744 F.3d 167 (1st Cir. 2014), in which two police officers were charged and convicted of drug and firearm offenses. The case arose from an FBI reverse sting - Operation Guard Shack-during which the FBI recruited two police officers to assist the agency in combatting police corruption in Puerto Rico. Officer I posed as a corrupt policeman with close ties to a mid- to high-level local drug dealer, and Officer II played the role of the dealer. The defendant officers were Raquel Delgado-Marrero (Delgado) and Angel Rivera-Claudio (Rivera), working partners at the Antillas Police Precinct in San Juan, Puerto Rico. The Rule 608(b) issue in the case involved only Delgado, and the discussion here is largely confined to her.

\section{Getting Involved}

Delgado began as a municipal police officer in her late 20s. Before the sting operation, she had five years of experience on the force, established a clean disciplinary record without a single administrative complaint filed against her, and received the Municipal Police Woman of 2009 award.

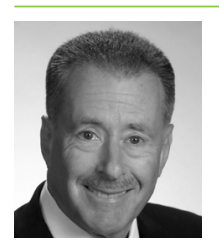

STEPHEN A. SALTZBURG is the Wallace and Beverley Woodbury University Professor at George Washington University School of Law in Washington, D.C. He is a past chair of the Criminal Justice Section and a regular columnist for Criminal Justice magazine. He is also author of the book, Trial Tactics, Third Edition (American Bar Association 2013), an updated and expanded compilation of his columns.
In mid-2009, Officer I, who had grown up with Delgado and gone to school and shared friends with her, reached out to her in his undercover role as a corrupt policeman. Although they had lost touch over the years, Officer I decided to renew contact after meeting with Delgado's ex-husband on an unrelated matter. Officer I learned from her ex-husband that Delgado was now divorced and had several part-time jobs providing nighttime security at veterinary clinics and pubs in "unsafe locations"- a term the officer interpreted to mean places where drug trafficking occurred.

Obtaining Delgado's phone number from the exhusband, Officer I called and talked with her twice. But despite instructions from the FBI, he failed to record either call. Finally, on July 20, 2009, Officer I made a third phone call and recorded a conversation with Delgado in which it was clear that during the previous calls she had already accepted his invitation to act as security during a drug transaction for which she and an unnamed fellow officer (later identified as Rivera) would be paid $\$ 2,000$ each.

Three days later, Officer I recorded another call in which he explained to Delgado how and where the transaction would take place. He told her that she and Rivera would be directed to a house and required to frisk two individuals involved in the drug buy to ensure that neither individual brought a gun into the house.

The next day, on July 24, 2009, Officer I was on the phone providing minute-by-minute directions to Delgado and Rivera that led them to an apartment outfitted by the FBI with hidden cameras and microphones, where Officer I and Officer II (the "drug dealer") were waiting. When Delgado and Rivera arrived, the two were offered refreshments, and, for about 30 minutes, the four of them engaged in friendly banter. When someone knocked on the door, Rivera was told to answer it and make certain no one entered the apartment armed. Officer I signaled Delgado to assist. After they cleared the man acting as the drug buyer, everyone moved back to the living room and the casual conversation continued until the buyer asked to see the "stuff," saying he was ready to leave. Rivera was told to retrieve a duffle bag that contained dummy packages wrapped to look like "bricks" of cocaine - and after examining the contents in view of both Rivera and Delgado, the buyer shook hands with everyone, put the bag over his shoulder, and left. Officer I handed Rivera $\$ 4,000$ in cash, Rivera counted it, and both Delgado and Rivera stated they were available for a second job.

The FBI did not arrest Delgado and Rivera until October 6, 2010, when they were indicted on four counts charging them with conspiracy to possess with intent to distribute cocaine, aiding and abetting another in an attempt to possess with intent to distribute cocaine, and knowingly possessing firearms in furtherance of drug trafficking. 
Delgado's Defense: Entrapment

Given the facts set forth above, it is not difficult to understand why Delgado did not deny she had agreed to participate in what was an apparent drug deal. It is much more difficult to understand Rivera's defense, which was that Rivera had no intention of participating in the transaction before Delgado lured him into it. Although there were taped calls between Officer I and Rivera, the other trial evidence implicated him as much as Delgado.

The government presented the testimony of Officers I and II and of the FBI agent who had prepared the apartment and provided the material used in the staged drug transaction. The government also introduced the two recorded calls between Officer I and Delgado, the video recording of the transaction, and five pictures of the "bricks" that were placed in the apartment by the FBI.

Delgado defended by claiming that she was entrapped by Officer I. Under federal law (unlike some states that focus objectively on the government's conduct), entrapment has two components: (1) the government has taken steps to induce the accused to engage in criminal conduct, and (2) the accused was not predisposed to engage in that conduct.

\section{Delgado's Testimony}

Delgado testified that over a period of a month, Officer I persistently offered her part-time employment, repeatedly called her, and sometimes took her out on dates; that he had a romantic, sexual affair with her in 2005 and 2009; and that several weeks after the sting operation, he took her out on a date during which they had sexual intercourse. Delgado contended that she finally gave in to Officer I's pressure.

The Rule 608(b) issue first arose before she took the stand during the cross-examination of Officer I and again when Delgado sought to offer the testimony of an acquaintance of Officer I, Brenda Rosa-Valentín.

\section{Cross-Examination of Officer |}

During cross-examination of Officer I, the government objected to a question regarding his recollection of his interactions with Rosa-Valentín. Delgado's counsel proffered at a sidebar conference that Rosa-Valentín would testify that Officer I had offered her money in exchange for providing contact information of potential police officers to entrap, and confessed to her his desire to kill a man he thought had wronged her brother. The judge indicated that he would not permit such questions unless he first heard from Rosa-Valentín, but he would permit Delgado to recall Officer I if a proper foundation were laid for the questions.

Delgado's counsel got Officer I to admit that he had offered money to Rosa-Valentín in exchange for police officers' names. Officer I said that he first mentioned the offer to Rosa-Valentín during a chance encounter while on duty when he responded to a late-night complaint of loud music during her birthday party at a commercial establishment. He denied, however, drinking beer at the party or allowing the party to continue after closing time in violation of a municipal ordinance. He also denied going to Rosa-Valentín's house more than 15 times in the days following the birthday party.

After the government rested, Delgado sought to call Rosa-Valentín as her counsel had previously proffered. The government objected that her testimony was irrelevant. Delgado's counsel repeated the proffer made during cross-examination, and the trial judge stated that he would hear the evidence outside the presence of the jury.

Outside the jury's presence, Rosa-Valentín testified that Officer I was her brother's life-long friend, that she had known him for more than 30 years, and that Officer I twice stated during funeral services for her brother's wife that he wanted to kill the man who he felt was responsible for her suicide. She also stated that Officer I told her about his shakedowns of drug dealers and fabrication of cases. She stated that Officer I had eight or nine beers at her birthday party and permitted it to continue until 4:30 a.m., and that Officer I came to her house the next day and persistently (sometimes up to seven times a day) for four months sought the names of police officers who could do some part-time work for him. He also offered her part-time work. The trial judge excluded the testimony as extrinsic evidence barred by Rule 608(b).

\section{The Court of Appeals' Holding}

The United States Court of Appeals for the First Circuit reversed, finding that the excluded testimony was not extrinsic evidence barred by Rule 608(b). The court instead reasoned "that Rosa-Valentín's testimony would have shown how Officer I went about his participation in Operation Guard Shack and would thus support [Delgado's] entrapment defense." (Delgado-Marrero, 744 F.3d at 180.) The court explained that Rosa-Valentín's testimony was similar to Delgado's and painted a picture of Officer I as relentlessly pursuing police officers as targets of the sting operation, including those who were not known as corrupt officers. Excerpts from the court's opinion highlight its reasoning:

Delgado avers that Rosa-Valentín's testimony contradicted Officer I's in several respects, and it is clear from the record that this was the case. Officer I, among other things, disavowed constantly visiting Rosa-Valentín after her birthday, whereas in her proffer she stated that it was precisely thereafter that Officer I harassed her for approximately four months, insisting that he be 
provided with contact information of police officers to do part-time work, sometimes going to her house more than seven times per day. Rule 608(b) does not preclude the introduction of this type of impeachment evidence.

More importantly, however, we agree with Delgado that Rosa-Valentín's testimony would have shown how Officer I went about his participation in Operation Guard Shack and would thus support her entrapment defense.

It is black-letter law that an entrapment defense has two elements: (1) government inducement of the accused to engage in criminal conduct, and (2) the accused's lack of predisposition to engage in such conduct. In connection with the inducement prong, Rosa-Valentín and Delgado painted a similar picture of Officer I's relentless pursuit of Operation Guard Shack part-time workers. Rosa-Valentín testified that Officer I offered her large amounts of money and pursued her for four months - sometimes going to her house more than seven times a day - trying to win her over so that she would provide contact information for part-time employees. In Delgado's case, she testified that Officer I courted her almost daily for approximately one month before she capitulated.

Delgado's and Rosa-Valentín's testimonies similarly reflected that Officer I tried to lure them into Operation Guard Shack activities by appealing to their long-lasting friendships. Delgado's and Rosa-Valentín's testimonies also reflected that Officer I attempted to manipulate his way around potential targets' reluctance to participate in an Operation Guard Shack "part-time." ...

Furthermore, Rosa-Valentín's testimony supported the propensity prong of Delgado's entrapment defense. For example, Rosa-Valentín's testimony showed that Officer I's pursuit of potential Operation Guard Shack targets was not limited to corrupt officers. In this regard, she testified that Officer I persistently asked her for contact information of police officers, even though she told him she knew only officers seemingly involved in legitimate part-time work (her exact words on this were: "They worked at gas stations, that kind of thing"). Rosa-Valentín also testified that Officer I invited her to participate in a "part-time" herself, despite the fact that she had no criminal record, links to the drug-trafficking trade, or involvement with the police force. Delgado testified similarly, stating that her untarnished criminal record shows that she had no inclination to engage in illegal activities before Officer I's month-long pursuit.

(Id. at 179-81 (citations omitted) (internal quotation marks omitted).)

The court of appeals was critical of the government's argument concerning Rule 608(b), observing that the government's entire argument in its brief was that "[t]he court correctly found [Rosa-Valentín's] testimony inadmissible under Rule 608(b), which only permits inquiry into prior conduct if the conduct is probative of the witness's character for truthfulness or untruthfulness." (Id. at 181 (alterations in original).) The court responded to this argument by saying, "We have stated many times that such a lackadaisical effort is insufficient to carry the day." (Id.) More importantly, however, the court specifically held that the excluded evidence was not barred by Rule 608(b) because it was probative of Delgado's entrapment defense.

\section{An Important Point}

The court of appeals recognized something that must be kept in mind: "While it may be true that RosaValentín's testimony incidentally called into question Officer I's character for truthfulness, without more, such an effect does not render the testimony inadmissible." (Id.) In short, evidence that is offered for a proper purpose (here, to prove entrapment) may have the additional effect of impeaching a witness such as Officer I, but when offered for a permissible purpose that evidence is not excluded by Rule 608(b).

\section{Other Government Arguments}

Although the focus here is on Rule 608(b), two other government arguments warrant brief mention. First, the government argued that the testimony by RosaValentín would have been improper "collateral" impeachment. This argument serves to remind that there is no prohibition in the Federal Rules of Evidence on impeachment on a collateral matter. There is only Rule 608(b)'s ban on extrinsic evidence offered for a particular purpose. Arguments about "collateralness" are decided under Federal Rule of Evidence 403, and in this case the court of appeals clearly identified the importance of the excluded evidence. 
Second, the government argued that Rosa-Valentín's testimony was improper prior bad acts testimony and was properly excluded under Federal Rule of Evidence 404(b)(1). This argument serves to remind that even when Rule 608(b) is not a bar to admission of evidence, another rule might be. But in this case, the evidence was used to show the methods used by Officer I to carry out his duties in the reverse sting operation, not to show his character generally.

\section{Lessons}

1. There is no general rule excluding evidence as collateral. Arguments about the collateral nature of evidence are properly addressed under Rule 403.

2. Rule 608(b)'s ban on extrinsic evidence is limited to situations in which a party seeks to offer evidence of acts that a witness has denied for the purpose of showing that those acts occurred and suggest that the witness is an untruthful person.

3. Evidence offered to show that a police officer engaged in acts that might demonstrate entrapment are not offered to suggest that the officer is untruthful.

4. If the officer denies the acts relied on to prove entrapment, evidence that the acts occurred might have the incidental effect of impeaching the officer, but as long as the acts are offered to prove entrapment they are offered for a permissible purpose.

5. Courts of appeal do not appreciate arguments made in a single sentence to defend an important decision of a trial judge that is central to a defendant's criminal appeal. 